\title{
LES CLASSIQUES DE LA MÉCANIQUE DES FLUIDES \\ ET DE L'HYDRAULIQUE
}

SÉRIE PUBLIÉE SOUS LA DIRECTION DE ENZO O. MACAGNO

Les textes de cette série seront publiés sans corrections d'aucune sorte, excepté lorsqu'il s'agira d'erreurs typographiques évidentes. Le lecteur sera ainsi confronté avec le texte original tel qu'il se présentait. Les traductions seront aussi littérales que possible, de façon à permettre l'accès le plus direct au texte original.

Les suggestions concernant les textes à inclure dans cette série seront les bienvenues, spécialement si des indications précises sont données, dans le cas d'articles très longs ou de livres, sur les parties considérées comme les plus importantes.

\section{CLASSICAL WORKS IN FLUID MECHANICS AND HYDRAULICS}

\author{
A SERIES SELECTED BY ENZO O. MACAGNO
}

No attempt to correct errors, if they would be detected, will be made, unless they appear as obvious misprints. Each reader will be confronted with the original writing as it was. Translations in this series are intended to be quite literal with the purpose of providing an access as direct as possible to the original form of the writing.

Suggestions to include material in this series will be most welcome, especially if indications are given of the excerpts that are considered valuable in the case of long papers or books.

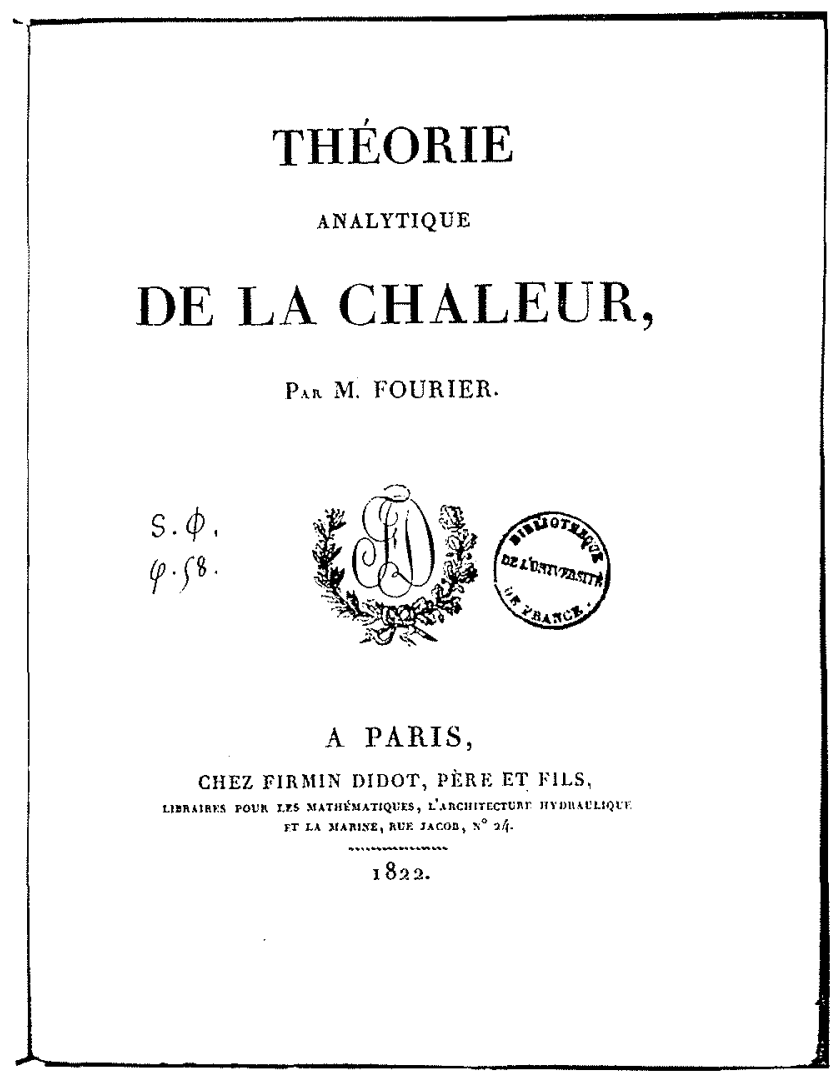

CHAPITRE II
EQUATIONS DIFFERENTIELLES
SECTION IX
REMARQUES GENERALES

English yersion from "The Analytical Theory
of Heat", by J. FourIER. Dover Publications,
New York.




\section{SECTION IX}

REMARQUTS GÉNÉRALIIS.

La recherche des lois du mouvement de la chaleur dans les solides consiste maintenant à intégrer les équations que nous avons rapportées : c'est l'objet des Chapitres suivants; nous terminerons celui-ci par des remarques générales sur la nature des quantités qui entrent dans notre analyse.

Pour mesurer ces quantités et les exprimer en nombres, on les compare à diverses sortes d'unités, au nombre de cinq, savoir l'unité de longueur, l'unité de temps, celle de la température, celle du poids et enfin l'unité qui sert à mesurer les quantités de chaleur. On aurait pu choisir pour cette dernière unité la quantité de chaleur qui élève un volume donné d'une certaine substance depuis la température 0 jusqu’à la température 1 . Le choix de cette unité serait préférable à plusieurs égards à celui de la quantité de chaleur nécessaire pour convertir une masse de glace d'un poids donné en une masse pareille d'eau, sans élever la température 0 . Nous n'avons adopté cette dernière unité que parce qu'elle était en quelque sorte fixée d'avance dans plusieurs Ouvrages de Physique; au reste, cette supposition n'apporterait aucun changement dans les résultats du calcul.

158.

Les éléments spécifiques qui déterminent dans chaque corps les effets mesurables de la chaleur sont au nombre de trois, savoir: la conducibilité propre, la conducibilité relative à l'air atmosphérique et la capacité de chaleur.

Les nombres qui expriment ces quantités sont, comme la pesanteur spécifique, autant de caractères naturels propres aux diverses substances.

Nous avons déjà remarqué (art. 36) que la conducibilité de la surface serait mesurée d'une manière plus exacte si l'on avait des observations suffisantes sur les effets de la chaleur rayonnante dans les espaces vides d'air.

On peut voir, comme nous l'avons annoncé dans la Section I du Chapitre I (art. 11), qu'il n'entre dans le calcul que trois coefficients spécifiques $K, b, c$; ils doivent être déterminés par des observations et nous indiquerons par la suite les expériences propres à les faire connaître avec précision.

Le nombre $C$, qui entre dans le calcul, est toujours multiplié par la densité $D$, c'est-à-dire par le nombre d'unités de poids qui équivalent au poids de l'unité de volume; ainsi ce produit CD peut être remplacé par le coefficient $c$. Dans ce cas, on doit entendre, par capacité spécifique de chalcur, la quantité nécessaire pour élever de la température 0 à la température 1 l'unité de volume d'une substance donnée et non l'unité de poids de cette substance. C'est pour ne pas s'éloigner des définitions communes que l'on a tapporté dans cet Ouvrage la capacité de chaleur au poids et non au volume; mais il serait préférable d'employer le coefficient $c$, tel que nous venons de le définir; alors il n'entrera dans les expressions analytiques aucune grandeur mesurée par l'unité de poids; on aura sculement à considérer:

$1^{\circ}$ La dimension linéaire $x$, la température $v$ et le temps $t$;

$2^{\circ}$ Les coefficients $c, b$ et $\mathrm{K}$.

Les trois premières quantités sont des indéterminées, et les trois autres sont, pour chaque substance, des éléments constants que l'expérience fait connaitre. Quant à l'unité de surface et
SECTION IX.

GenERAL REMARKS

157.

The investigation of the laws of movement of heat in solids now consists in the integration of the equations which we have constructed; this is the object of the following chapters. We conclude this chapter with general remarks on the nature of the quantities which enter into our analysis.

In order to measure these quantities and express them numerically, they must be compared with different kinds of units five in number namely the unit of length, the unit of time that of temperature, that of weight, and finally the unit which serves to measure quantities of heat. For the last unit, we might have chosen the quantity of heat which raises a given volume of a certain substance from the temperature 0 to the temperature 1. The choice of this unit would have been preferable in many respects to that of the quantity of heat required to convert a mass of ice of a given weight, into an equal mass of water at 0 , without raising its temperature. We have adopted the last unit only because it had been in a manner fixed beforehand in several works on physics; besides, this supposition would introduce no change into the results of analysis.

\section{8.}

The specific elements which in every body determine the measurable effects of heat are three in number, namely, the conducibility proper to the body, the conducibility relative to the atmospheric air, and the capacity for heat. The numbers which express these quantities are, like the specific gravity, so many natural characters proper to different substances.

We have already remarked, Art. 36, that the conducibility of the surface would be measured in a more exact manner, if we had sufficient observations on the effects of radiant heat in spaces deprived of air.

It may be seen, as has been mentioned in the first section of Chapter I., Art. 11, that only three specific coefficients, $K, b, C$, enter into the investigation; they must be determined by observation; and we shall point out in the sequel the experiments adapted to make them know with precision.

159.

The number $C$ which enters into the analysis, is always multiplied by the density $D$, that is to say, by the number of units of weight which are equivalent to the weight of unit of volume; thus the product $C D$ may be replaced by the coefficient $c$. In this case we must understand by the specific capacity for heat, the quantity required to raise from temperature 0 to temperature 1 unit of volume of a given substance, and not unit of weight of that substance.

With the view of not departing from the common definition, we have referred the capacity for heat to the weight and not to the volume; but it would be preferable to employ the coefficient $c$ which we have just defined; magnitudes measured by the unit of weight would not then enter into the analytical expressions: we should have to consider only, 1st, the linear dimension $x$, the temperature $v$, and the time $t ; 2$ nd, the coefficients $c, b$, and $K$. The three first quantities are undetermined, and the three others are, for each substance, constant elements which experiment determines. As to the unit of surface and the unit 
à l'unité de volume, elles n'ont rien d'absolu et dépendent de l'unité de longueur.

160.

Il faur maintenant remarquer que chaque grandeur indéterminée ou constante a une dimension qui lui est propre et que les termes d'une même équation ne pourraient pas être comparés, s'ils n'avaient point le même exposant de dimension. Nous avons introduit cette considération dans la Théorie de la chaleur pour rendre nos définitions plus fixes et servir à vérifier le calcul; elle dérive des notions primordiales sur les quantités : c'est pour cette raison que, dans la Géométric et dans la Mécanique, elle équivaut aux lemmes fondamentaux que les Grecs nous ont laissés sans démonstration.

$$
161 .
$$

Dans la théorie analytique de la chaleur, toute équation (E) exprime une relation nécessaire entre des grandeurs subsistantes $x$, $t, v, c, b, \mathrm{~K}$. Cette relation ne dépend point du choix de l'unité de longueur, qui de sa nature est contingent; c'est-à-dire que, si l'on prenait une unité différente pour mesurer les dimensions linéaires, l'équation (E) serait encore la même. Supposons donc que l'unité de longueur soit changée et que sa seconde valcur soit équivalente à la promière divisée par $m$. Une quantité quelconque $x$ qui, dans l'équation $(E)$, représente une certaine ligne $a b$ et qui, par conséquent, désigne un certain nombre de fois l'unité de longucur, deviendra $m x$, afin de correspondre à la même grandeur $a b$; la valeur $t$ du temps et la valeur $v$ de la température ne seront point changées; il n'en sera pas de même des éléments spécifiques $b, \mathrm{~K}, c$ : le premier $b$ deviendra $\frac{b}{m^{2}}$; car il exprime la quantité de chaleur qui sort, pendant l'unité de temps, de l'unité de surface à la température 1. Si l'on examine avec attention la nature du coefficient $K$, tel que nous l'avons défini dans les articles 68 et 135 , on reconnaîtra qu'il devient $\frac{K}{n}$; car le flux de chaleur est en raison directe de l'étendue de la surface et en raison inverse de la distance des deux plans infinis (art. 72). Quant au coefficient $c$ qui représente le produit $C D$, il dépend aussi de l'unité de longueur et devient $\frac{c}{m^{3}}$; donc l'équation (E) ne doit subir aucun changement si l'on écrit, au lieu de $x, m x$, et en même temps $\frac{K}{m}$, $\frac{b}{m^{2}}, \frac{c}{m^{3}}$ au lieu de $\mathrm{K}, b, c$; le nombre $m$ disparaîtra de luimême après ces substitutions : ainsi la dimension de $x$ par rapport à l'unité de longueur est 1 ; celle de $K$ est -1 , celle de $b$ est -2 , et celle de $c$ est -3 . Si l'on attribue à chaque quantité son exposant de dimension, l'équation sera homogène, parce que chaque terme aura le même exposant total. Les nombres tels que $s$, qui représentaient des surfaces ou des solides, ont la dimension 2 dans le premier cas, et la dimension 3 dans le second. Les angles, les sinus et autres fonctions trigonométriques, les logarithmes ou exposants de puissance sont, d'après les principes du calcul, des nombres absolus qui ne changent point avec l'unité de longueur; on doit donc trouver leur dimension égale à 0 , qui est celle de tous les nombres abstraits.

Si l'unité de temps, qui était d'abord 1 , devient $\frac{1}{n}$, le nombre $t$ sera $n t$ et les nombres $x$ et $\nu$ ne changeront point. Les coefficients $\mathrm{K}, b, c$ seront $\frac{\mathrm{K}}{n}, \frac{b}{n}, c$. Ainsi, les dimensions de $x$, $t, v$, par rapport à l'unité de temps, sont $0,1,0$ ct celles de $\mathrm{K}$, $h, c$, sont - $1,-1,0$.

Si l'unité de température était changée, en sorte que la tem- of volume, they are not absolute, but depend on the unit of length.

It must now be remarked that every undertermined magnitude or constant has one dimension proper to itself, and that the terms of one and the same equation could not be compared, if they had not the same exponent of dimension. We have introduced this consideration into the theory of heat, in order to make our definitions more exact, and to serve to verify the analysis; it is derived from primary notions on quantities; for which reason, in geometry and mechanics, it is the equivalent of the fundamental lemmas which the Greeks have left us without proof.

161.

In the analytical theory of heat, every equation $(E)$ expresses a necessary relation between the existing magnitudes $x, t, v, c, b$, $K$. This relation depends in no respect on the choice of the unit of length, which from its very nature is contingent, that is to say, if we took a different unit to measure the linear dimensions, the equation $(E)$ would still be the same. Suppose then the unit of length to be changed, and its second value to be equal to the first divided by $m$. Any quantity whatever $x$ which in the equation $(E)$ represents a certain line $a b$, and which, consequently, denotes a certain number of times the unit of length, becomes $m x$, corresponding to the same length $a b$; the value $t$ of the time, and the value $v$ of the temperature will not be changed; the same is not the case with the specific elements $b, K, c:$ the first, $b$, becomes $\frac{b}{m^{2}}$; for it expresses the quanticy of heat which escapes, during the unit of time from the unit of surface at the temperature 1 . If we examine attentively the nature of the coefficient $K$, as we have defined it in Articles 68 and 135, we perceive that it becomes $\frac{K}{m}$; for the flow of heat varies directly as the area of the surface, and inversely as the distance between two infinite planes (Art. 72). As to the coefficient $c$ which represents the product $C D$, it also depends on the unit of length and becomes $\frac{c}{m^{3}}$; hence equation (E) must undergo no change when we write $m x$ instead of $x$, and at the same time $\frac{\mathrm{K}}{m}, \frac{b}{m^{2}}, \frac{c}{m^{3}}$, instead of $K, b, c$; the number $m$ disappears after these substitutions: thus the dimension of $x$ with respect to the unit of length is 1 , that of $K$ is -1 , that of $b$ is -2 , and that of $c$ is -3 . If we attribute to each quantity its own exponent of dimension, the equation will be homogeneous, since every term will have the same total exponent. Numbers such as $S$, which represent surfaces or solids, are of two dimensions in the first case, and of three dimensions in the second. Angles, sines, and other trigonometrical functions, logarithms or exponents of powers, are, according to the principles of analysis, absolute numbers which do not change with the unit of length; their dimensions must therefore be taken equal to 0 , which is the dimension of all abstract numbers.

If the unit of time, which was at first 1 , becomes $\frac{1}{n}$, the number $t$ will become $n t$, and the numbers $x$ and $v$ will not change. The coefficients $K, b, c$ will become $\frac{\mathrm{K}}{n}, \frac{b}{n}, c$. Thus the dimensions of $x, t, v$, with respect to the unit of time are $0,1,0$, and those of $K, b, c$, are $-1,-1,0$.

If the unit of temperature be changed, so that the tempera- 
pérature 1 devînt celle qui répond à un autre effet que l'ébullition de l'eau, et si cet effet exigeait une température moindre, qui fût à celle de l'eau bouillante dans le rapport de 1 au nombre $p, v$, deviendrait $v p, x$ et $t$ conserveraient leurs valeurs et les coefficients $\mathrm{K}, b, c$ seraient $\frac{\mathrm{K}}{p}, \frac{b}{p}, \frac{c}{p}$.

Le Tableau suivant représente les dimensions des trois indéterminées et des trois constantes, par rapport à chaque sorte d'unité :

Longueur. Durée. Température.

\begin{tabular}{|c|c|c|c|c|c|}
\hline \multirow[t]{3}{*}{ Exposant de } & dimension de & $x \ldots \ldots$ & 1 & 0 & 0 \\
\hline & $\gg$ & $t \ldots \ldots$ & 0 & 1 & 0 \\
\hline & $\gg$ & $v \ldots \ldots$ & 0 & 0 & 1 \\
\hline La conducil & lité spécifique & K...... & -1 & -1 & -1 \\
\hline La conducin & lité de la su & ace $h \ldots$ & -2 & -1 & -1 \\
\hline La capacité & de chaleur & & -3 & 0) & -1 \\
\hline
\end{tabular}

162.

Si l'on conservait les coefficients $C$ et $D$ dont le produit a été représenté par $c$, on aurait encore à considérer l'unité de poids et l'on trouverait que l'exposant de dimension, par rapport à l'unité de longueur, est -3 pour la densité $D$ et 0 pour $C$.

En appliquant la règle précédente aux différentes équations et à leurs transformées, on trouvera qu'elles sont homogènes par rapport à chaque sorte d'unité et que la dimension de toute quantité angulaire ou exponentielle est nulle. Si cela n'avait point lieu, on aurait commis quelque erreur dans le calcul ou l'on y aurait introduit des expressions abrégées.

Si l'on choisit, par exemple, l'équation (b) de l'article 105

$$
\frac{\partial v}{\partial t}=\frac{K}{\mathrm{CD}} \frac{\partial^{2} v}{\partial x^{2}} \quad \frac{b l}{\mathrm{CDS}} v
$$

on trouve que, par rapport à l'unité de longueur, la dimension de chacun des trois termes est 0, qu'elle est 1 pour l'unité de température et -1 pour l'unité de temps.

Dans l'équation $v=\mathrm{Ae}^{-v \sqrt{\frac{2 h}{\pi l}}}$ de l'article 76 , la dimension linéaire de chaque terme est 0 , et l'on voit que celle de l'exposant $x \sqrt{\frac{2 b}{K l}}$ est toujours nulle, soit pour l'unité linéaire, soit pour la durée ou la température. ture 1 becomes that which corresponds to an effect other than the boiling of water; and if that effect requires a less temperature, which is to that of boiling water in the ratio of 1 to the number $p$; $v$ will become $v p, x$ and $t$ will keep their values, and the coefficients $K, b, c$, will become $\frac{K}{p}, \frac{b}{p}, \frac{c}{p}$.

The following table indicates the dimensions of the three undetermined quantities and the three constants, with respect to each kind of unit.

Length. Duration. Température.

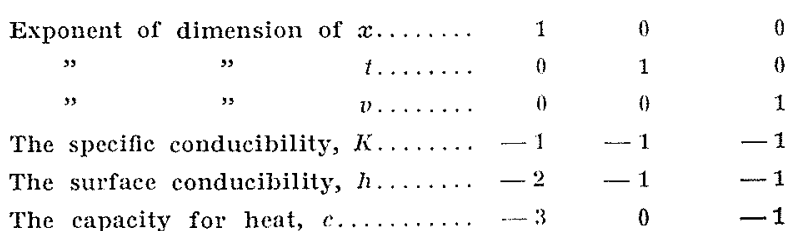

162.

If we retained the coefficients $C$ and $D$, whose product has been represented by $c$, whe should have to consider the unit of weight, and we should find that the exponent of dimension, with respect to the unit of length, is -3 for the density $D$, and 0 for $C$.

On applying the preceding rule to the different equations and their transformations, it will be found that they are homogeneous with respect to each kind of unit, and that the dimension of every angular or exponential quantity is nothing. If this were not the case, some error must have been committed in the analysis, or abridged expressions must have been introduced.

If, for example, we take equation (b) of Art. 105,

$$
\frac{d v}{d t}=\frac{\mathrm{K}}{\mathrm{CD}} \frac{d^{2} v}{d x^{2}}-\frac{b l}{\mathrm{CDS}} v
$$

we find that, with respect to the unit of length, the dimension of each of the three terms is 0 ; it is 1 for the unit of temperature, and -1 for the unit of time.

In the equation $v=A e^{-x} \sqrt{\frac{2 h}{k l}}$ of Art. 76 , the linear dimension of each term is 0 , and it is evident that the dimension of the exponent $x \sqrt{\frac{2 b}{K l}}$ is always nothing, whatever be the units of length, time, or temperature. 